\title{
Study of the effect of two wastewater treatment plants (WWTP's) discharges on the benthic macroinvertebrate communities' structure of the River Tinto (Portugal)
}

\author{
Jesus T. ${ }^{1,}{ }^{*}$, Monteiro A. ${ }^{1,2}$, Abreu I. ${ }^{1}$ and Guerreiro M. J. ${ }^{1}$ \\ ${ }^{1}$ UFP Energy, Environment and Health Research Unit (FP-ENAS), Universidade Fernando Pessoa, Portugal. \\ Praça 9 de Abril, 349, Porto, Portugal. \\ 2 LSRE-LCM, Faculdade de Engenharia da Universidade do Porto, Portugal. \\ * Corresponding author: tjesus@ufp.edu.pt
}

Received: 09/11/18 Accepted: 29/07/19

\begin{abstract}
Study of the effect of two wwt's discharges on the benthic macroinvertebrate communities' structure of the River Tinto (Portugal)

The Water Framework Directive (DQA-2000/60/ EC) establishes, as one of its main objectives, the achievement of good ecological status of water bodies and introduces the concept of "ecological status", which includes the study of a broad set of parameters and factors to determining the health of an ecosystem. This work is part of a project whose main objective is the rehabilitation of a small urban river in the north of Portugal, the Tinto river, that presents a high degree of environmental degradation. This work aims to study the effect of the two wastewater treatment plants (WWTP's) discharges in the structure of the benthic macroinvertebrate communities. The study compares results (metrics and indices) obtained from the analysis of benthic macroinvertebrates samples collected in river sections upstream and downstream of the discharges of WWTP's, between october 2015 and july 2017, and values of hydro-morphological and physico-chemical parameters. Although the benthic macroinvertebrate communities are very conditioned by the bad status of the Tinto river, in the sections downstream of the WWTP's the macroinvrtebrates communities present characteristics that indicate a higher degree of environmental disturbance.
\end{abstract}

Key words: water quality, urban water course, benthic macroinvertebrates, wastewater treatment plant

\section{RESUMO}

Estudo do efeito de duas estações de tratamento de águas residuais na estrutura da comunidade de macroinvertebrados do rio Tinto (Portugal)

A Diretiva Quadro da Água (DQA-2000/60/EC) estabelece como um dos seus objetivos principais, a obtenção de um bom estado ecológico dos sistemas aquáticos, e introduz o conceito de "estado ecológico", que inclui o estudo de um amplo conjunto de parâmetros e fatores na determinação da saúde de um ecossistema. Este trabalho é parte de um projeto cujo principal objetivo é a reabilitação de um pequeno rio do norte de Portugal, o rio Tinto, que corre ao longo de uma área urbana, e que apresenta um elevado nivel de degradação ambiental. O objetivo do presente trabalho é estudar o efeito das descargas de duas estações de tratamento de águas residuais (ETAR's) na estrutura das suas comunidades de macroinvertebrados bentónicos. $O$ estudo compara resultados (métricas e indices) obtidos a partir da análise de amostras de macroinvertebrados bentónicos, recolhidas em troços do rio a montante e a jusante das descargas das ETAR's, entre outubro de 2015 e julho de 2017 e valores de parâmetros hidro-morfológicos e fisico-químicos. Os resultados permitem verificar que apesar de as comunidades de macroinvertebrados bentónicos se encontrarem muito condicionadas pelo mau estado do rio Tinto, as áreas a jusante das ETAR's apresentam características que indiciam, ainda, um maior grau de perturbação ambiental.

Palavras chave: qualidade da água, rio urbano, macroinvertebrados bentónicos, estação de tratamento de águas residuais urbanas 


\section{INTRODUCTION}

Rivers have historicaly been development enabler, but not without environmental costs. Urban rivers have been used to supply drinking water, water for industry and for irrigation purposes, as well as used for transportation and waste disposal (Meyer et al., 2005; Parrinello, 2014). Urban rivers have been embanked to promote development and prevent flooding, but due to the rapid urbanization (Shheehan, 2001; Cohen, 2003) with uncontrolled riverbank settlements, agricultural practices, and discharge of treated and untreated effluents (Li et al., 2010; Birk et al., 2012), their quality has been compromised (Grim et al., 2000; Paul \& Meyer, 2001; Meyer et al., 2005; Poulton et al., 2015).

All these factors contribute to a significant degradation of the quality of these ecosystems with consequent changes in their abiotic characteristics and in their biotic communities (Quinn \& Hickey, 1990; Dodds, 2006; Nothington \& Hershey, 2005; Young et al., 2008; Zhang et al., 2014).

The Water Framework Directive (Diretive 2000/60/CE) establishes a framework for community action (transposed into Portuguese law by Law No $58 / 2005$ of 29 December, as amended by Decree-Law no. 245/2009, of September 22, and by Decree-Law no. 77/2006, of March 30, amended by Decree-Law no. 103/2010, of September 24) to prevent and reduce pollution, promote sustainable water use, protect the environment and improve the state of aquatic ecosystems and introduces the term "ecological status". The "ecological status" is based on the use of many parameters (hydro-morphological, physical, chemical and biological) and tools (indexes, metrics, techniques of multivariate analysis, study of the structure and functioning of communities) to determine the overall health status of an ecosystem.

In small urban watercourses with a reduced flow rate, the discharge of treated and untreated urban effluents assumes great importance in its dynamics. Discharges of these effluents usually cause an increase in the amount of organic matter and nutrients in the water, which promotes an increase in microbial activity (Gulis \& Suberkropp, 2003) and the consequent reduction of dissolved oxygen concentration in water (Dodds,
2006). These changes usually result in significant changes in the structure of biotic communities (Suckling, 1982; Fukushima \& Kanada, 1999; Kosmala et al., 1999; Dyer \& Wang, 2002; Pascoal et al., 2005; Suozzo, 2005).

The importance of these discharges depends on the profile and structure of the river channel, the frequency of riffles and pools, height of the water column, riverbed materials and river flow to volume and discharge-duration relationship (Folt et al., 1999; Culp \& Baird, 2006; Gucker et al., 2006). Poor water quality may compromise populations health that are in direct contact with rivers (Haseena et al., 2017).

Numerous studies show that benthic macroinvertebrate communities are affected by the discharge of wastewater treatment plants (WWTP's), even in rivers already under other environmental stressors (Ortiz \& Puig, 2007; Spanhoff et al., 2007; Grantham et al., 2012). These changes are often difficult to evaluate by a single water quality index such as IBMWP (Alba Tercedor et al., 2002), but become more evident when using metrics or miltimetric indices, such as IPtIN, as suggested by the water Framework Directive (Heiskanen et al., 2004; INAG, 2009; Munné \& Pratt, 2009; Birk et al., 2012).

Communities structure changes may be highlighted by multivariate analysis techniques using sample spatial ordering, based on the ecological and physiological characteristics of the organisms (Rieradevall et al., 1999; Vivas et al., 2002; Gerhardt et al., 2004; Castillo et al., 2006; Hrodey et al., 2008).

There are still a few studies that identify metrics or combinations of metrics that can predict changes in biotic conditions capable of identifying the effects of urbanization. This difficulty arises due to the occurrence of multiple agents of environmental disturbances. Nonetheless, there is information on the urbanization effects on aquatic communities and the specific responses of some organisms to urban-related stressors (e.g., Yoder \& Rankin, 1995; Folt et al., 1999; Bruns, 2005; Culp \& Baird, 2006, O’Driscoll et al., 2010; Concepción et al., 2015; Meillére et al., 2015).

Therefore, the objectives of this study are:

1) Evaluate the influence of two WWTP's 
discharges on the Tinto River water quality and the benthic macrinvertebrates communities' structure of the river;

2) Relate the changes on the composition and structure of the macroinvertebrate communities with the changes in environmental conditions;

3 ) Identify the metrics and / or parameters that best describe the effects caused by the discharge of the WWTP's in the degradation of the quality of the Tinto river.

\section{METHODOLOGY}

\section{Study area}

The Tinto river is a small water course, about 11.4 $\mathrm{km}$ long, which source is at an elevation of $200 \mathrm{~m}$ at the Montes da Costa Park (Valongo) and flows to the right bank of the Douro river estuary, Porto (Fig. 1) (Pinho et al., 2009). The Tinto river is classified as a small Northern Portuguese river (INAG, 2008b), and runs through four municipalities (Valongo, Maia, Gondomar and Porto).

The watershed area is approximately 23.5 $\mathrm{km}^{2}$, dominated by granite rocks that occupy much of the central and western zone of the water- shed. In the periphery of the granitic zone there are rocks of the pre-Ordovician shale-grauwacke complex. Along the banks of the river it is possible to find more recent deposits in the form of fluvial terraces and clayey deposits from the bottom of the valley (Pinho et al., 2009). The climate is Csb (dry summer), according to the Koppen-Geiger system classification. The annual average temperature is $14.6{ }^{\circ} \mathrm{C}$, the average annual rainfall is $1223 \mathrm{~mm}$, with an average of nine wet days per month (Climatedata, 2017).

For several centuries, the Tinto river was considered an important natural resource to maintain a small medieval village (Lemos, 2010). In the last decades, part of the natural and built heritage of the Tinto river basin was degraded, mainly due to the high urban pressure and the increasing level of pollution (Vieira, 2009). Nowadays, the Tinto river is characterized by a strong human activity occupying its banks with small agricultural fields and dwellings, and by some diffuse or punctual entry of the untreated effluents that flow directly to the river, and the discharges of two WWTP's, resulting in a significant increase in the water pollution level (Vieira, 2009), and contributing to unpredict

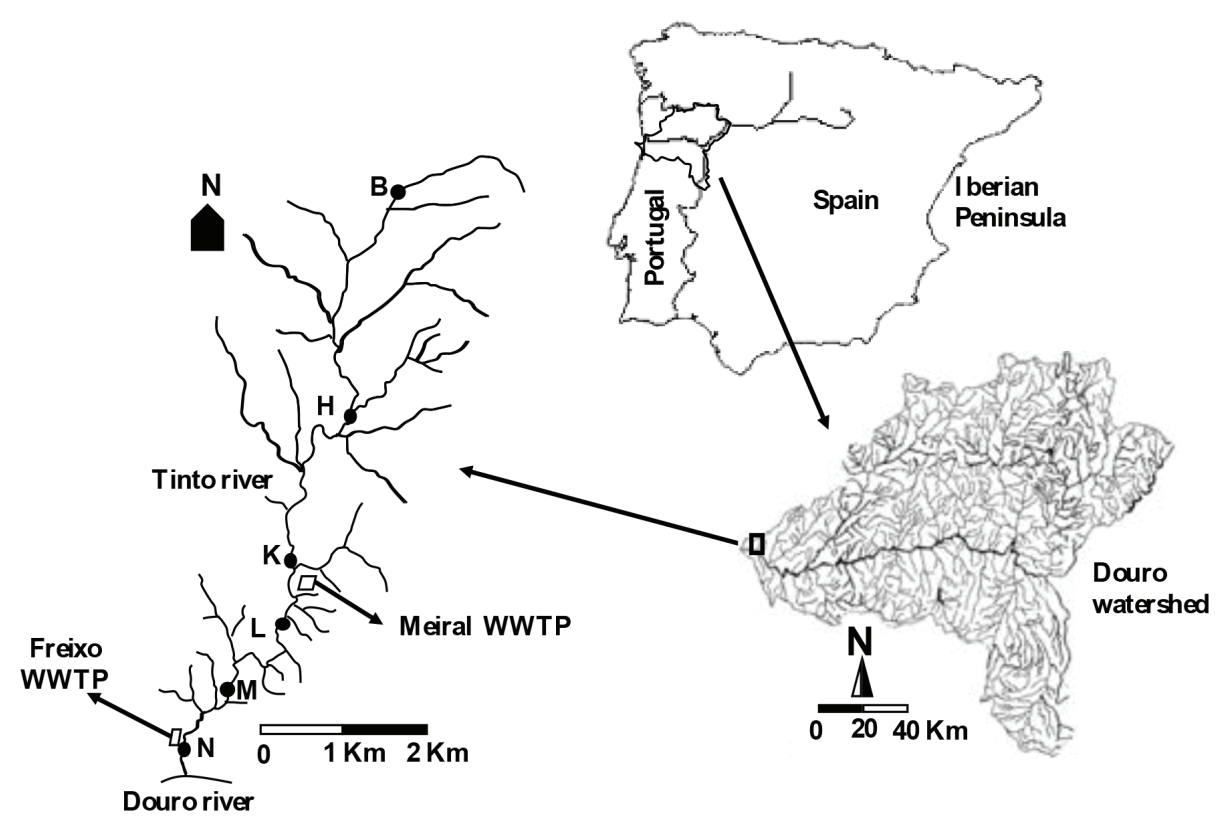

Figure 1. Sampling sites in the Tinto river (Portugal). Pontos de amostragem no rio Tinto. 
Table 1. Abiotic parameters analyzed at Tinto River sampling points, their methods, units and bibliography references. Parâmetros abióticos analisados nos pontos de amostragem do rio Tinto, metodologias, unidades e referências bibliográficas.

\begin{tabular}{|c|c|c|c|c|}
\hline Parameter & Method & Periodicity & Units & $\begin{array}{c}\text { Bibliographic } \\
\text { reference }\end{array}$ \\
\hline Width and Depth & In loco, with a meter & \multirow{3}{*}{ Monthly } & $\mathrm{m}$ & \multirow{2}{*}{ (Jesus, 2001) } \\
\hline Water velocity & In loco with a flow meter & & $\mathrm{m} / \mathrm{s}$ & \\
\hline Flow & $\begin{array}{l}\text { In lab, calculated through the with, } \\
\text { depth and water velocity data }\end{array}$ & & $\mathrm{m}^{3} / \mathrm{s}$ & $\begin{array}{c}\text { (Platts et al., } \\
1983)\end{array}$ \\
\hline Canopy & $\begin{array}{l}\text { In loco, by visual observation of area of } \\
\text { the river with shadow }\end{array}$ & \multirow{3}{*}{ Semestral } & \multirow{3}{*}{$\%$} & \multirow{3}{*}{ (Jesus, 2001) } \\
\hline Macrophytes & $\begin{array}{l}\text { In loco, by visual observation of } \\
\text { covered area of the river bed }\end{array}$ & & & \\
\hline Substrate & $\begin{array}{l}\text { In loco, by visual observation of the } \\
\text { proportion of each substrate } \\
\text { component: mud, silt, gravel, pebbles } \\
\text { and blocks }\end{array}$ & & & \\
\hline Conductivity & $\begin{array}{l}\text { In loco, with an electrometric, using a } \\
\text { portable apparatus }\end{array}$ & \multirow{8}{*}{ Monthly } & $\mu \mathrm{S} / \mathrm{cm}$ & \\
\hline $\mathrm{pH}$ & $\begin{array}{l}\text { In loco, with an electrometric, using a } \\
\text { portable apparatus }\end{array}$ & & $\begin{array}{l}\text { Sorensen } \\
\text { scale }\end{array}$ & \\
\hline Oxygen saturation & $\begin{array}{l}\text { E In loco, with an electrometric, using a } \\
\text { portable apparatus }\end{array}$ & & $\% \mathrm{O} 2$ & \\
\hline $\begin{array}{l}\text { Biochemical Oxygen } \\
\text { demand }\left(\mathrm{BOD}_{5}\right)\end{array}$ & $\begin{array}{l}\text { In lab, by dissolved oxygen } \\
\text { determination wth Winkler method }\end{array}$ & & $\mathrm{mg} \mathrm{O} 2 / \mathrm{L}$ & \multirow{5}{*}{ APHA, 1999} \\
\hline Ammonium $\left(\mathrm{NH}_{4}{ }^{+}\right)$; & \multirow{4}{*}{ In lab, by colorimetric reaction } & & $\mathrm{mg} \mathrm{NH}_{4}{ }^{+} / \mathrm{L}$ & \\
\hline Nitrites $\left(\mathrm{NO}_{2}^{-}\right)$ & & & $\mathrm{mg} \mathrm{NO}_{2}^{-} / \mathrm{L}$ & \\
\hline Nitrates $\left(\mathrm{NO}_{3}^{-}\right)$ & & & $\mathrm{mg} \mathrm{NO}_{3}-\mathrm{L}$ & \\
\hline Total Phosphorous $\left(\mathrm{P}_{\text {total }}\right)$ & & & $\mathrm{mg} \mathrm{P} / \mathrm{L}$ & \\
\hline
\end{tabular}

erosion and deposition. Fish fauna has not been observed for some years, and only benthic invertebrates and some aquatic birds were observed there (Lemos, 2010).

Data was collected at six sampling sites in the Tinto river, between October 2015 and July 2017. The six sampling sites (Fig. 1) were selected such as to study the effect of the two wastewater treatment plants located in the river's last 4 $\mathrm{km}$ 's and identified as one of the main pollution sources of the water and taking into account its general characteristics (Jesus et al., 2017): B closest to the source is used as reference point; $\mathrm{H}$ - closest to the study area but still not under the influence of any WWTP; K and L - upstream and downstream of the Meiral WWTP, respectively; $\mathrm{M}$ and $\mathrm{N}$ - upstream and downstream of the Freixo WWTP.

The two WWTP's treat urban sewage from Gondomar (Meiral WWTP) and Porto (Freixo WWTP) and discharge the treated water in the Tinto river upstream of the sampling sites $L$ and M, respectively. The Meiral WWTP performs primary and secondary treatment to 65000 population equivalent and an average daily flow of
$770 \mathrm{~m} 3 / \mathrm{h}$. Due to rainwater infiltration there may be excess flow to the WWTP and a bypass ocasionaly discharges part of the untreated effluent directly into the river. The Freixo WWTP treats urban effluents from the Porto city with about 170000 population equivalent and average daily flow of $1500 \mathrm{~m}^{3} /$ day with primary, secondary and tertiary treatments with disinfection of treated wastewater by UV radiation. Treated flows from both WWTP's are, sometime, like the natural river flow, being relevant to the river water quality because they discharge organic and nutrient compounds.

\section{Sampling}

The present study was conducted between October 2015 and July 2017 with monthly or semestral determination of some environmental parameters (physical and chemical and hydro-morphological) using the methodologies suggested by the documents resulting from the application of the Water Framework Directive in Portugal (Table 1).

Sampling of benthic macroinvertebrates was performed quarterly (at the end of each season) 
using a hand net $(30 \times 30 \mathrm{~cm}, 250 \mu \mathrm{m}$ mesh) collecting samples by mesohabitat following the official Portuguese sampling protocols (INAG, 2008a). The collected samples were preserved in formalin $4 \%$ and transported to the laboratory for later identification and counting of the organisms to the family level, except for Oligochaeta (INAG, 2009). When the number of organisms was greater than 300 per sample, a sub-sampling was performed (INAG, 2008a).

\section{Data analysis}

Two indices were calculated based on the river Tinto's hydro-morphological parameters: QBR (Munné et al., 1998), successfully used in the Iberian Peninsula for assessment of the conservation state of the river banks, and a visual evaluation index of Habitat (AVH) for high-gradient rivers (EPA, 1999), successfully applied in many countries to assess the state of the riverbed taking into account its structure and capacity to accommodate aquatic life (Barbour, 1997). Values were compared to the water quality classes proposed by Casatti et al. (2006).

The benthic macroinvertebrate community assessement was based on some metrics and two water biological quality indices (Table 2): IBMWP (Alba-Tercedor et al., 2002), successfully applied in the Iberian Peninsula and the basis for the assessment of water quality in Portugal, and the Rácio de Qualidade Ecológica resulting from the application of the official multi-metric index for rivers of Northern Portugal - $\operatorname{IPtI}_{\mathrm{N}}$ (INAG, 2009). The metrics presented in Table 2 were selected considering their sensitivity to organic contamination and the factors used to calculate $\mathrm{IPtI}_{\mathrm{N}}$.

The community was analysed in terms of its taxonomic composition and their ecological and physiological traits. The organisms were grouped by respiratory physiology, feeding type, preference for habitat and mobility, and preferences to current speed regime (Table 3) (Jesus, 2002; Jesus, 2008).

Box \& Whisker plots show the spatial variation of all analysed parameters and metrics. Mean values of the physico-chemical parameters, the hydromorphological parameters and of the macroinvertebrates metrics were used as an input to a Principal Component Analysis (PCA) to detect a spatial pattern of the sampling sites distribution with standardized values to reduce the variability imposed by the different units in wich the variables were determined (Clarke \& Warwick, 1994).

A non-multidimensional scaling analysis (n-MDS) determined whether the WWTPs influence the composition and the structure of the benthic macroinvertebrate communities. This analysis orders the samples based on their

Table 2. Biological water Quality and metrics calculated with the benthic macroinvertebrate data, and bibliography references. Indices de qualidade biológica da água e métricas calculados com base nos dados de macroinvertebrados e referências bibliográficas.

\begin{tabular}{|c|c|c|}
\hline Index/metrics & Definition & $\begin{array}{c}\text { Bibliographic } \\
\text { reference }\end{array}$ \\
\hline IBMWP & Iberian Bio-Momitoring Working Party Index & $\begin{array}{c}\text { (Alba Tercedor et } \\
\text { al., 2002) }\end{array}$ \\
\hline RQE & Ecological quality ratio & (INAG, 2009) \\
\hline Abundance & Total number of organisms & (INAG, 2009) \\
\hline Richness & Total number of taxa & (INAG, 2009) \\
\hline Diversity & Shannon diversity Index & (INAG, 2009) \\
\hline Equitability & Pielou equitability Index & (INAG, 2009) \\
\hline EPT families & Total number of Ephemeroptera, Plecoptera and Trichoptera families & (INAG, 2009) \\
\hline Diptera families & Total number of Diptera families & (INAG, 2009) \\
\hline$\%$ Trichoptera & Percent of Trichoptera larvae & (EPA, 1999) \\
\hline$\%$ CHIRONOMIDAE & Percent of CHIRONOMIDAE larvaes & (EPA, 1999) \\
\hline$\%$ clingers & $\begin{array}{l}\text { Percent of insect larvae having fixed retreats or adaptations for attachment to } \\
\text { surfaces in flowing water }\end{array}$ & (EPA, 1999) \\
\hline$\%$ reophiles & Percent of insect larvae having preferences for water with velocity under $0,3 \mathrm{~m} / \mathrm{s}$ & (EPA, 1999) \\
\hline $\begin{array}{l}\% \text { branchial and } \\
\text { cutaneous }\end{array}$ & Percent of insect larvae having branchial and/or cutaneous respiration & (EPA, 1999) \\
\hline
\end{tabular}


Table 3. Ecological and functional macroinvertebrate groups. Grupos de macroinvertebrados de acordo com as suas caracteristicas ecológicas e fisiológicas.

\begin{tabular}{|c|c|c|}
\hline Type of & Group & Definition \\
\hline \multirow{7}{*}{$\begin{array}{l}\text { Respiratory } \\
\text { groups }\end{array}$} & Aerial & Organisms that live on the water surface and that can use the atmospheric oxygen to breath \\
\hline & Aerial and Branchial & Organisms that have gills and can use the atmospheric oxygen to breath \\
\hline & Branchial & Organisms that live submerged and have gills to breath \\
\hline & Branchial and cutaneous & Organisms that live submerged and have gills to breath or have cutaneous respiration \\
\hline & Cutaneous & Organisms that live submerged and had cutaneous respiration \\
\hline & Pulmonar & Organisms that have a richly vascularized paleal cavity in the mantle that function as a "lung" \\
\hline & Special & Organisms that have special adaptations to live in water with a very low oxygen concentration \\
\hline \multirow{5}{*}{ Feeding groups } & Shredders & Chewing of detritus and macrophytes, mining of macrophytes and gougers of wood \\
\hline & Collectors & Suspension feeding, deposit feeding \\
\hline & Scrappers & Grazing/scraping of mineral and organic surfaces \\
\hline & Predators & Engulfing, piercing \\
\hline & Limnivorous & Substrate feeders \\
\hline \multirow{7}{*}{ n groups } & Skaters & $\begin{array}{l}\text { Adapted for life on the water surface where they feed on organisms trapped in the surface film, low-order } \\
\text { streams or margins of high-order rivers }\end{array}$ \\
\hline & Planktonics & Inhabiting open water, slow-flow or still, in high-order rivers \\
\hline & Swimmers & Insects adapted for swimming, semi-aquatic organisms \\
\hline & Clingers & $\begin{array}{l}\text { Possess behavioural or morphological adaptations for attachment to substrate surfaces, or that are sessile } \\
\text { or colonial }\end{array}$ \\
\hline & Sprawlers & $\begin{array}{l}\text { Inhabiting the surface of floating leaves of vascular plants or fine sediments in depositional habitats with } \\
\text { with adaptations for staying on the substrate }\end{array}$ \\
\hline & Climbers & Living and moving on vascular plants or detrital debris \\
\hline & Burrowers & Inhabiting fine sediments, some constructing discrete burrows, or ingesting their way through sediments \\
\hline \multirow{4}{*}{$\begin{array}{l}\text { Preference for } \\
\text { water velocity }\end{array}$} & Limnophiles & Inhabiting waters with velocity under $0.3 \mathrm{~m} / \mathrm{s}$ \\
\hline & Most limnophiles & Preference for waters with velocity under $0.3 \mathrm{~m} / \mathrm{s}$ \\
\hline & Reophiles & Inhabiting waters with velocity upper $0.3 \mathrm{~m} / \mathrm{s}$ \\
\hline & Most reophiles & Preference for waters with velocity upper $0.3 \mathrm{~m} / \mathrm{s}$ \\
\hline
\end{tabular}

Table 4. Values of the hydromorphological indexes calculated. Valores para os índices de qualidade do habitat.

Very good; 1 - Good; - Medium; $\square$ - Bad; $\square$ - Very bad;

\begin{tabular}{cccccccc}
\hline & Site B & Site H & Site K & Site L & Site M & Site N \\
\hline \multirow{4}{*}{$\begin{array}{c}\text { Riparian índex } \\
\text { (AVH) }\end{array}$} & october 2015 & 101 & 130 & 115 & 129 & 138 & 128 \\
\cline { 2 - 8 } & april 2016 & 103 & 132 & 117 & 131 & 136 & 124 \\
\cline { 2 - 8 } & october 2016 & 78 & 138 & 115 & 150 & 155 & 123 \\
\cline { 2 - 8 } & april 2017 & 84 & 115 & 91 & 136 & 147 & 108 \\
\hline \multirow{4}{*}{$\begin{array}{c}\text { Habitat index } \\
\text { (QBR) }\end{array}$} & october 2015 & 5 & 20 & 15 & 30 & 40 & 45 \\
\cline { 2 - 8 } & april 2016 & 5 & 20 & 15 & 30 & 40 & 45 \\
\cline { 2 - 8 } & october 2016 & 0 & 15 & 0 & 40 & 45 & 45 \\
\cline { 2 - 8 } & april 2017 & 0 & 20 & 0 & 35 & 60 & 60 \\
\hline
\end{tabular}

taxonomic composition and their attributes, using the Euclidean distance applied to the composition of each sample. For the cluster analysis on taxonomic composition and physiological characteristics, a K-means analysis was carried out, with validation of the groups of samples through an analysis of similarities
(ANOSIM). All these analyzes were performed based on the percentage distribution of the organisms by the different groups considered. The statistical analysis was performed using STATISTICA 6.0 and the n-MDS and ANOSIM analysis using PRIMER 5.2.2.

\section{RESULTS}

\section{Hydro-morphological parameters}

The sampling sites show banks conservation status varying from medium to bad at sites L, M and $N($ QBR between 30 and 60) and very bad at sites $\mathrm{B}, \mathrm{H}$ and $\mathrm{K}$ (QBR between 0 and 20), a habitat quality ranging from bad to medium at site $\mathrm{B}$ (AVH between 78 and 103), and between medium and good at the other sampling sites (AVH between 91 and 155) (Table 4).

There is little canopy $(<10 \%)$ at $\mathrm{B}, \mathrm{H}$ and $\mathrm{K}$ sampling sites, whereas sites $\mathrm{L}, \mathrm{M}$ and $\mathrm{N}$ show values above $15 \%$ (Fig. 2). Riverbed vegetation (macrophytes) does not abound at 

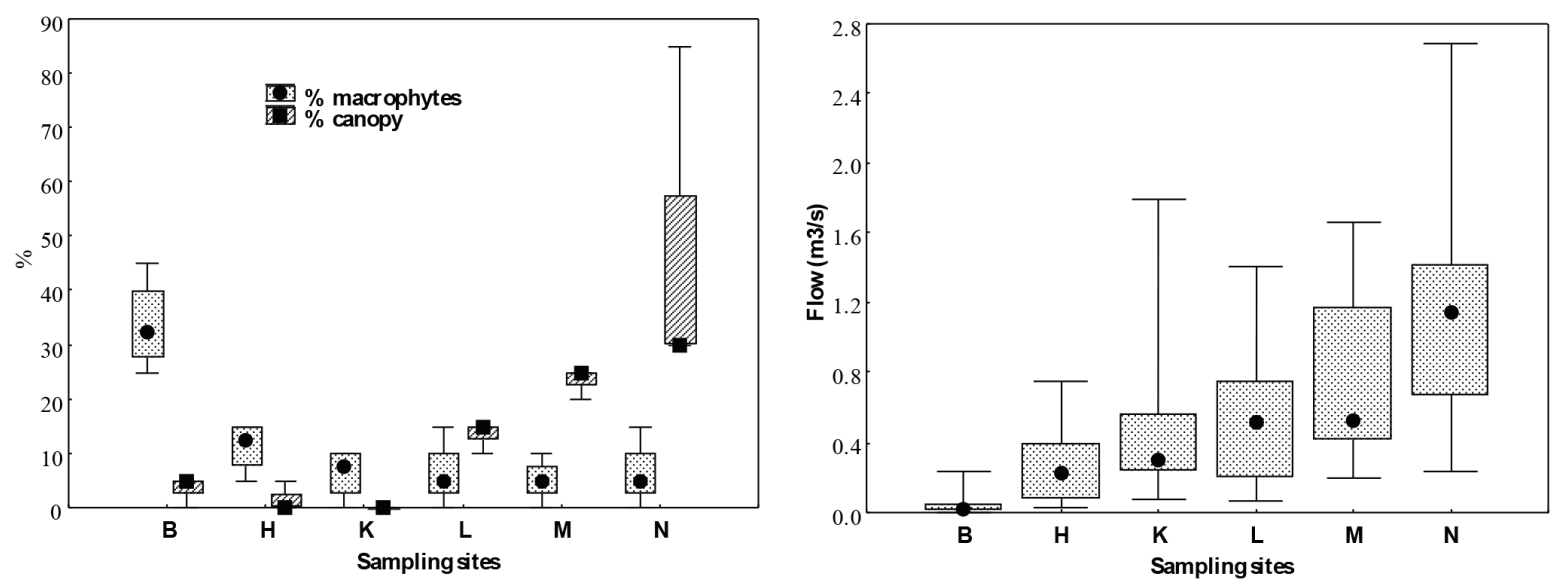

Figure 2. Graphical representation of the spatial variation of the hydromorphological (left: canopy and macrophytes; right: flow). Representação gráfica da variação dos parâmetros hidro-morfológicos (esquerda: cobertura e macrófitas; direita: caudal).

- - median; 汶- 25\% - 75\%; 工- minimum and maximum

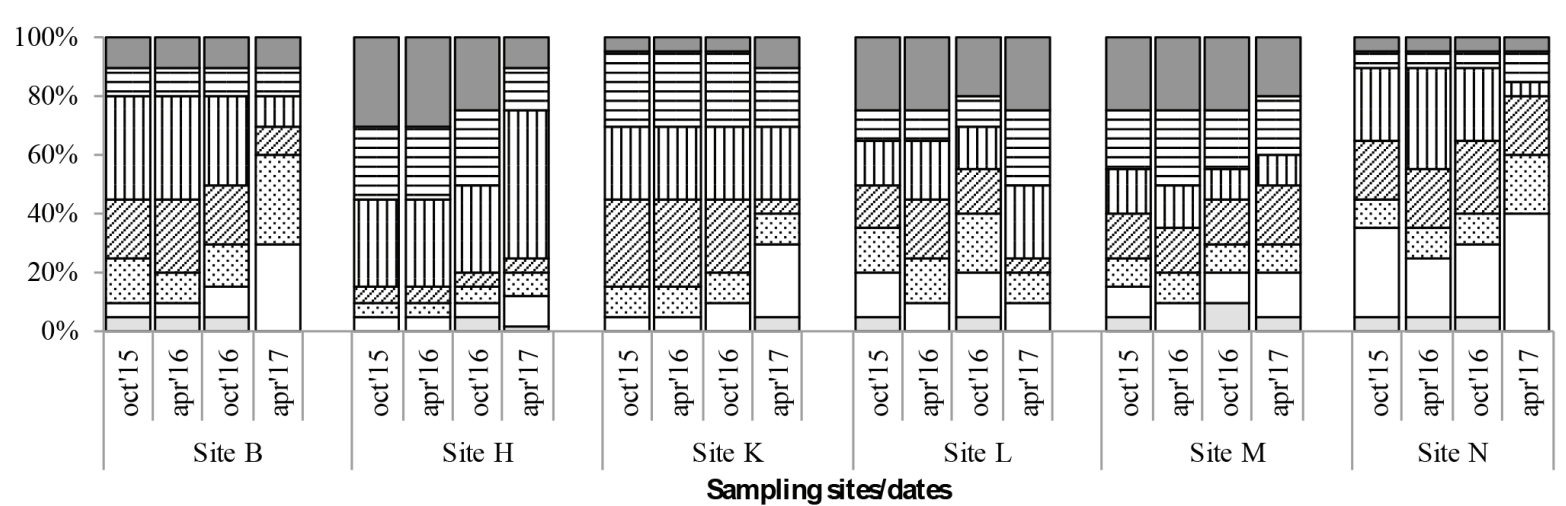

$\square$ mud $\square$ silt $\square$ gravel $\square$ pebble $\square$ cobble $\boxminus$ small blocks $\square$ blocks

Figure 3. Substrate composition in each sampling site. Composição do substrato em cada ponto de amostragem.

most sites $(<10 \%)$, except at site B $(>25 \%)$ where flow values are smaller and more constant throughout the sampling period (Fig. 2 ). At the other sampling sites, flow values show greater variation and increase towards downstream, as expected.

The substrate contains cobbles, small blocks and blocks with little mud and silt at most sampling points, except at point $\mathrm{N}$ where silt is about $20 \%$ of the substrate throughout the study period (Fig. 3).

These results suggest three groups of sampling sites (96.6 \% confidence; $p$-value $0.034)$ with a decreasing quality towards downstream (Fig. 4):

1) Site B: banks in a state of extreme degradation (QBR between 0 and 5) (Table 4), absence of canopy $(<10 \%)$ and an habitat quality between medium and bad (AVH between 78 and 101), (Table 4, Fig. 2 and 3), which reflect the diversity of habitat material and the highest percentage of macrophytes ( 25 to $50 \%$ ), (Table 4, Fig. 2 and 3);

2) Sites $\mathrm{H}$ and $\mathrm{K}$ : they present a state of 

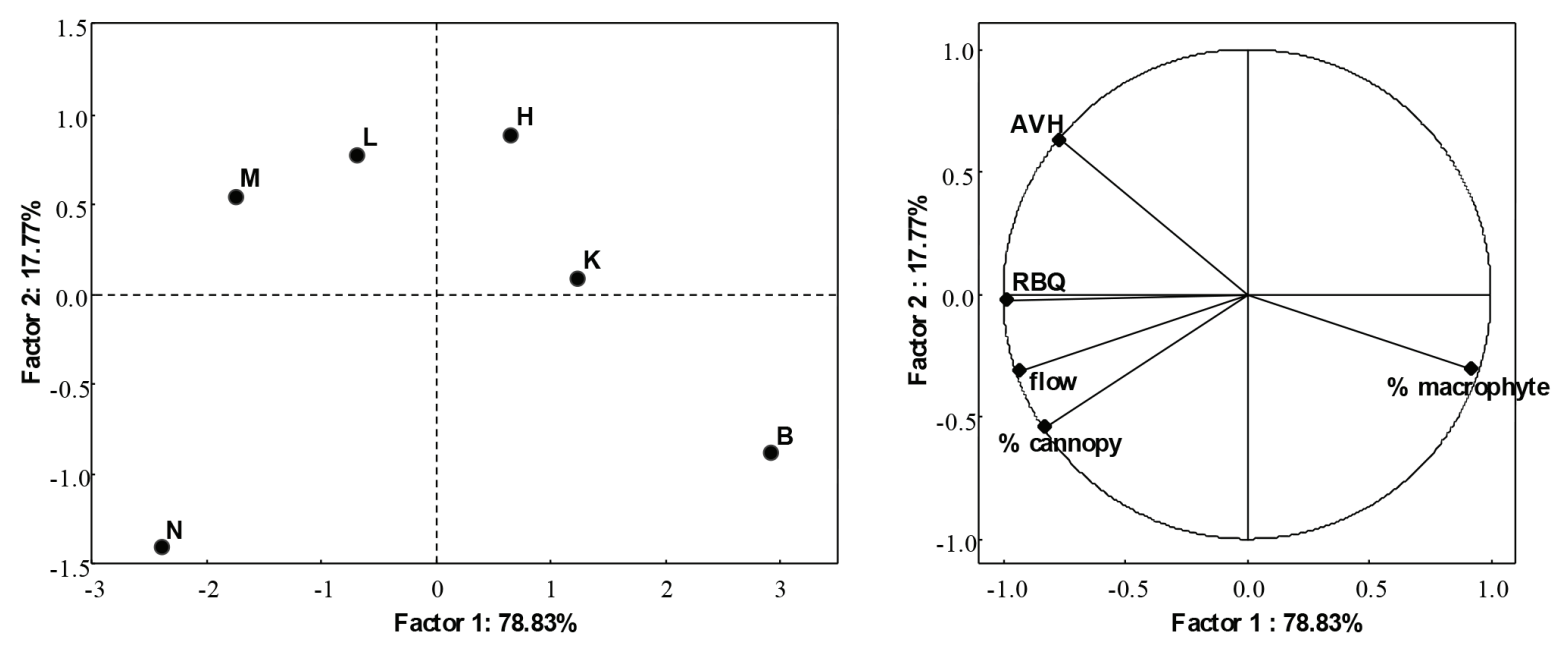

Figure 4. Principal components analysis (PCA) based on the mean values of the hydromorphological parameters: left) sample ordination of all sampling sites in the space formed by the two first factors; right) correlation circle of the hydromorphological parameters with the two first factors. Análise em componentes principais (PCA) baseada nos valores médios dos parâmetros hidro-morfológicos: esquerda) ordenação dos pontos de amostragem no espaço formado pelos dois primeiros fatores; direita) círculo de correlação dos parâmetros hidro-morfológicos com os dois primeiros fatores.

extreme degradation of the banks (QBR between 0 and 20), with little or no riparian vegetation (canopy between 0 and $5 \%$ ), present some aquatic vegetation (macrophytes between 0 and $15 \%$ ) (Fig. 2) and habitat quality values corresponding to a quality between medium and good (AVH between 91 and 150), which reflects the great variability of hydrological conditions accompanied by the presence of a great diversity of materials that form the substrate (Table 4, Fig. 2 and 3);

3) Sites L, M and N: banks with conservation status varying between bad and medium (QBR between 30 and 60), higher canopy values (up to $90 \%$ ) habitat quality between good and medium (AVH between 108 and 155) (Table 4), which reflects the higher flow variability and a more equitable distribution of the materials constituting the substrate (Table 4, Fig. 2 and 3).

\section{Physical and chemical parameters}

Based on the spatial variability of the physical-chemical parameters (Fig. 5):

- All sampling sites have median $\mathrm{pH}$ values compatible with the maintenance of aquatic life ( $\mathrm{pH}$ between 6 and 9);
- Dissolved oxygen values at the majority of samples are mostly compatible with aquatic life $(>60 \%)$;

- Except for site $\mathrm{B}, \mathrm{BOD}_{5}$, ammonia, nitrates, nitrites and phosphates, parameters related to the presence of organic matter and other nutrients in water, are higher than those indicated by the WFD to define a good water quality $\left(\right.$ BOD $_{5} \leq 6$ $\mathrm{mg} / \mathrm{L}$, nitrates $\leq 25 \mathrm{mg} / \mathrm{L}$, Ammonia $\leq 1 \mathrm{mg} / \mathrm{L}$, phosphates $\leq 0.1 \mathrm{mg} / \mathrm{L}$ );

- Conductivity shows a range of median values that defines three groups of sampling points: site B with values between 50 and $200 \mu \mathrm{S} / \mathrm{cm}$, sites $\mathrm{H}$ and $\mathrm{K}$, values between 50 and $450 \mu \mathrm{S} / \mathrm{cm}$, sites L , $\mathrm{M}$ and $\mathrm{N}$ with the highest values, between 400 and $500 \mu \mathrm{S} / \mathrm{cm}$ and maximum values between 550 and $700 \mu \mathrm{S} / \mathrm{cm}$.

The results of PCA suggest three groups of sampling sites ( $88 \%$ confidence; $p$-value 0.12 ) (Fig. 6):

1) Site B: with the lower values of conductivity, $\mathrm{BOD}_{5}$ and nutrient concentration, and the higher values of oxygen saturation (Fig. 5);

2) Sites $\mathrm{H}$ and $\mathrm{K}$ : show intermediate values of conductivity, $\mathrm{BOD}_{5}$ and concentration of the various nutrients, but still relatively high values 

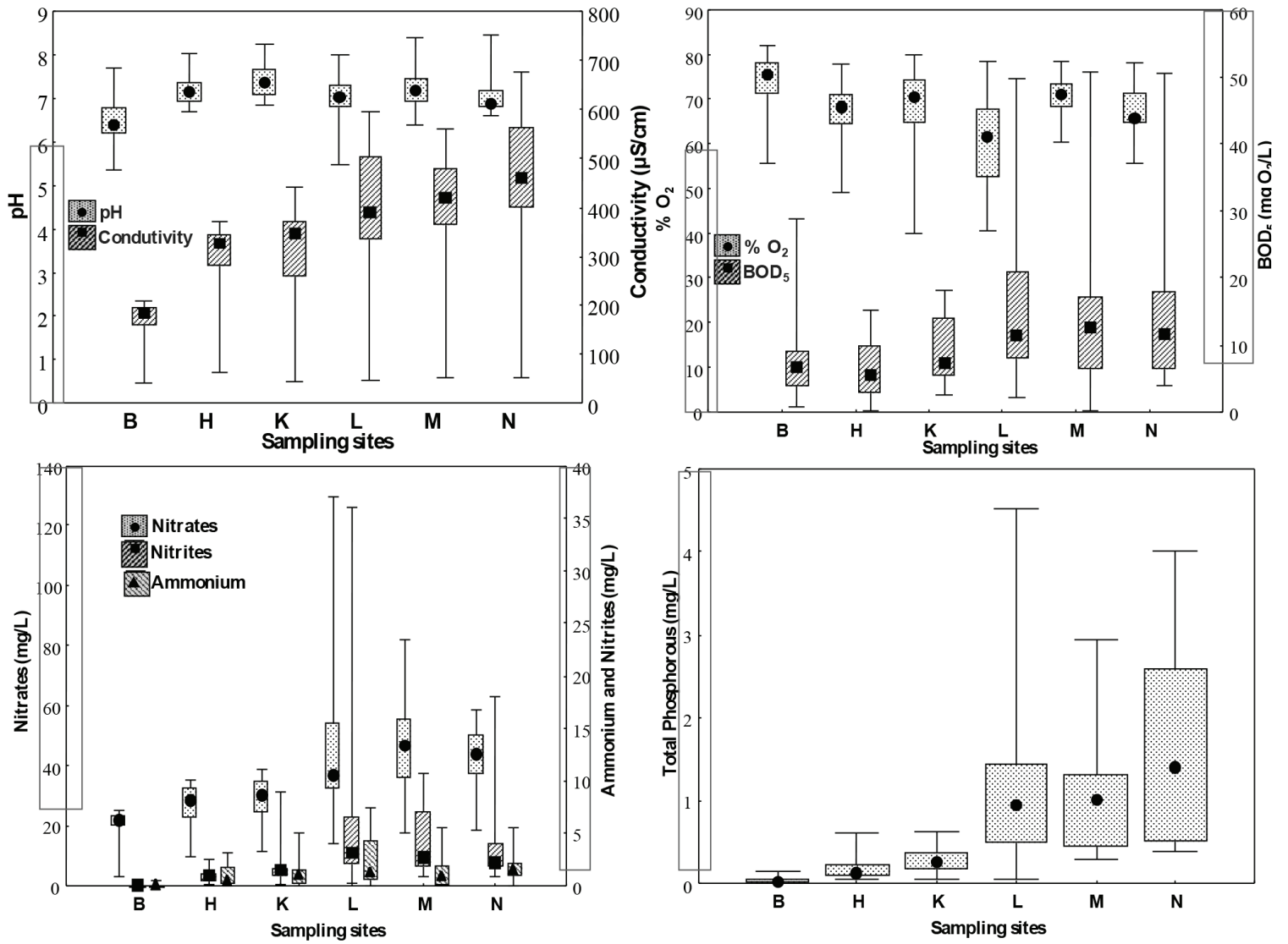

Figure 5. Graphical representation of the spatial variation of the physical and chemical parameters (upper-left: ph and conductivity; upper-right: Oxygen saturation and BOD5; lower-left: Nitrates, nitrites and ammonium; lower-right: Total phosphorus). Representação gráfica da variação dos parâmetros hidro-morfológicos (superior-esquerda: pH e condutividade; superior-direita: saturação de oxigénio e CBO5; inferior - esquerda: nitratos, nitritos e amónia; inferior-direita: fósforo total).

- - median; 2 - 25\% - 75\%; 工 - minimum and maximum; - values outer of limits to good water quality by Water framework directive

Table 5. Values of the biological water quality indexes. Valores para os índices de qualidade biológica da água.

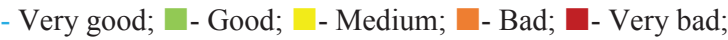

\begin{tabular}{clcccccc}
\hline & & Site B & Site H & Site K & Site L & Site M & Site N \\
\hline \multirow{5}{*}{ IBMWP } & december 2015 & 36 & 29 & 20 & 11 & 7 & 12 \\
\cline { 2 - 8 } & march 2016 & 7 & 24 & 19 & 12 & 16 & 21 \\
\cline { 2 - 8 } & jun 2016 & 16 & 33 & 19 & 16 & 15 & 12 \\
\hline \multirow{5}{*}{ september 2016 } & 20 & 32 & 17 & 12 & 21 & 11 \\
\cline { 2 - 8 } EQN & december 2016 & 28 & 15 & 30 & 23 & 12 & 7 \\
\cline { 2 - 8 } & march 2017 & 36 & 21 & 25 & 19 & 12 & 12 \\
\cline { 2 - 8 } jun 2017 & 27 & 15 & 21 & 9 & 8 & 11 \\
\cline { 2 - 8 } & december 2015 & 0.32 & 0.27 & 0.22 & 0.19 & 0.14 & 0.21 \\
\cline { 2 - 8 } & march 2016 & 0.17 & 0.24 & 0.22 & 0.22 & 0.24 & 0.23 \\
\cline { 2 - 8 } & jun 2016 & 0.23 & 0.28 & 0.35 & 0.23 & 0.21 & 0.13 \\
\cline { 2 - 8 } & september 2016 & 0.25 & 0.27 & 0.22 & 0.23 & 0.23 & 0.2 \\
\cline { 2 - 8 } & december 2016 & 0.26 & 0.22 & 0.29 & 0.21 & 0.21 & 0.09 \\
\cline { 2 - 8 } & march 2017 & 0.34 & 0.22 & 0.25 & 0.25 & 0.20 & 0.2 \\
\cline { 2 - 8 } & jun 2017 & 0.27 & 0.22 & 0.22 & 0.10 & 0.13 & 0.3 \\
\hline
\end{tabular}



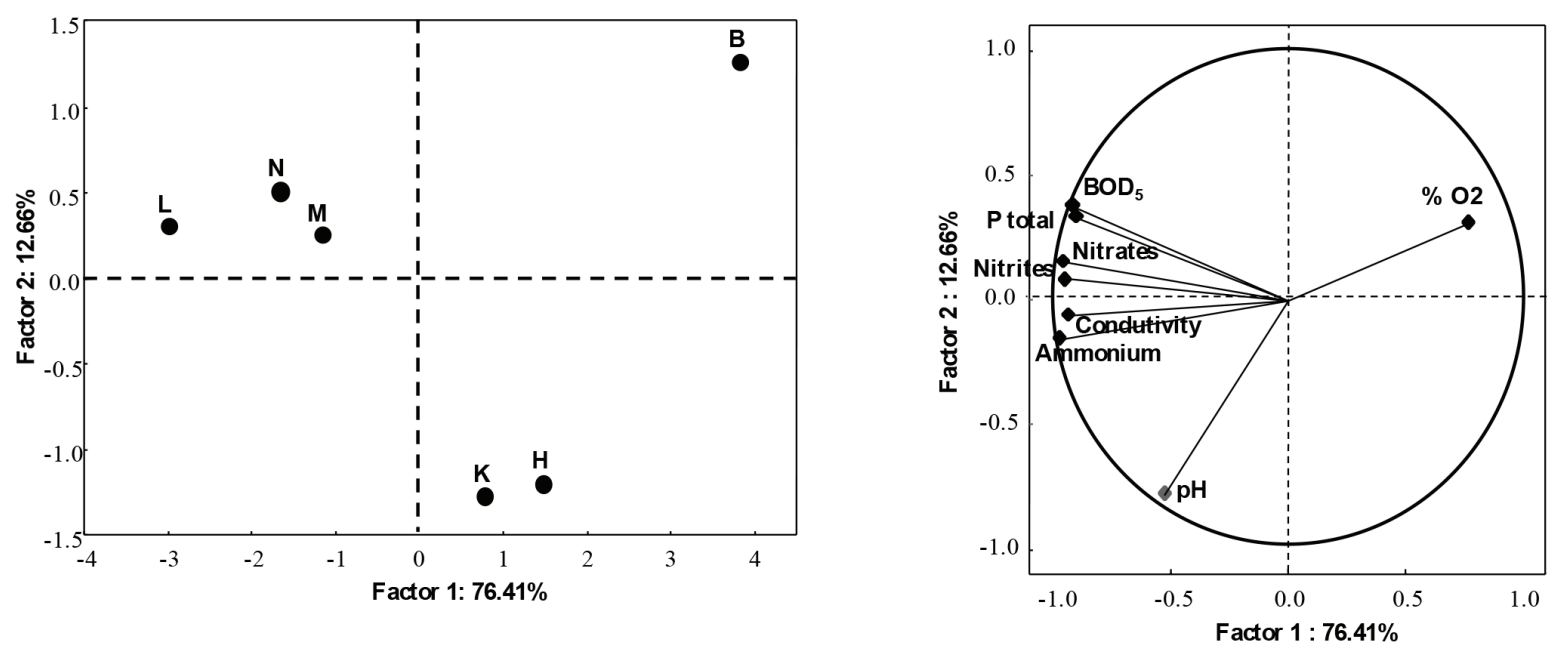

Figure 6. Principal components analysis (PCA) based on the mean values of the physical and chemical parameters: left) sample ordination of all sampling sites in the space formed by the two first factors; right) correlation circle of the physical and chemical parameters with the two first factors. Análise em componentes principais (PCA) baseada nos valores médios dos parâmetros fisico-químicos: esquerda) ordenação dos pontos de amostragem no espaço formado pelos dois primeiros fatores; direita) círculo de correlação dos parâmetros físico-químicos com os dois primeiros fatores.

of oxygen saturation (Fig. 5);

3) Sites L, M and N: with higher values of BOD5 and nutrients concentration (Fig. 5).

\section{Benthic macroinvertebrate communities}

The analysis of the calculated metrics shows that three groups of sampling points can be defined which reflect a deterioration of the biological water quality (Table 5 and Fig. 7):

1) Site B: biological water quality between medium and very bad, higher number of taxa (3 to 10), smaller number of organisms (maximum of 100) (Fig. S1, see supplementary information available at http://www.limnetica.net/en/limnetica) and presence of Trichoptera in some samples (Figs. S1, S2 see supplementary information available at http://www.limnetica.net/en/limnetica);

2) Sites $\mathrm{H}$ and $\mathrm{K}$ : water quality between bad and very bad, higher percentage of clingers and reophiles, intermediate values of diversity and equitability (Fig. S1, 11 and 12);

3) Sites L, M and N: very poor water quality in most determinations, higher number of individuals and lower number of taxa, lower median values of diversity and equitability, higher percentage of Diptera, especially CHIRONOMIDAE and lower percentage of organisms with branchial and/or cutaneous respiration and EPT (Fig. S1 and 9).

The communities found are mainly composed by organisms belonging to the Diptera and the Oligochaeta, also appearing Ephemeroptera in a smaller percentage, and occasionally some Mollusca (Fig. S2 and Fig. 8). At site B it is possible to find, occasionally, some Trichoptera. There is a dominance of organisms that present cutaneous and/or branchial respiration, and which present special respiratory strategies (predominantly at sites $\mathrm{L}, \mathrm{M}$ and $\mathrm{N}$ ). In some samples it is possible to find some organisms with pulmonar breathing (Fig. S2 and 9). There is a predominance of colletctors, limnivorous (mainly in points L, M and N) and shredders (Fig. S2 and 10).

Attending the habitat and locomotion mode of organisms, at the sampling sites $\mathrm{L}, \mathrm{M}$ and $\mathrm{N}$ there is a dominance of burrowers whereas at sites $\mathrm{B}, \mathrm{H}$ and $\mathrm{K}$ the climbers and clingers predominate. The swimmers are represented in all sampling sites, although in a smaller percentage at sites L, M and $\mathrm{N}$ (Fig. S2 and 11). At all sampling sites there is only a small percentage of strictly limnophilic 
organisms, being the communities constituted predominantly by organisms with great capacity of survival in places where the hydrological conditions vary in time (most limnophiles and most reophiles). Despite these general characteristics, there is some variability in the samples collected at the different sampling sites: only at site B was Trichoptera found in at least one of the samples
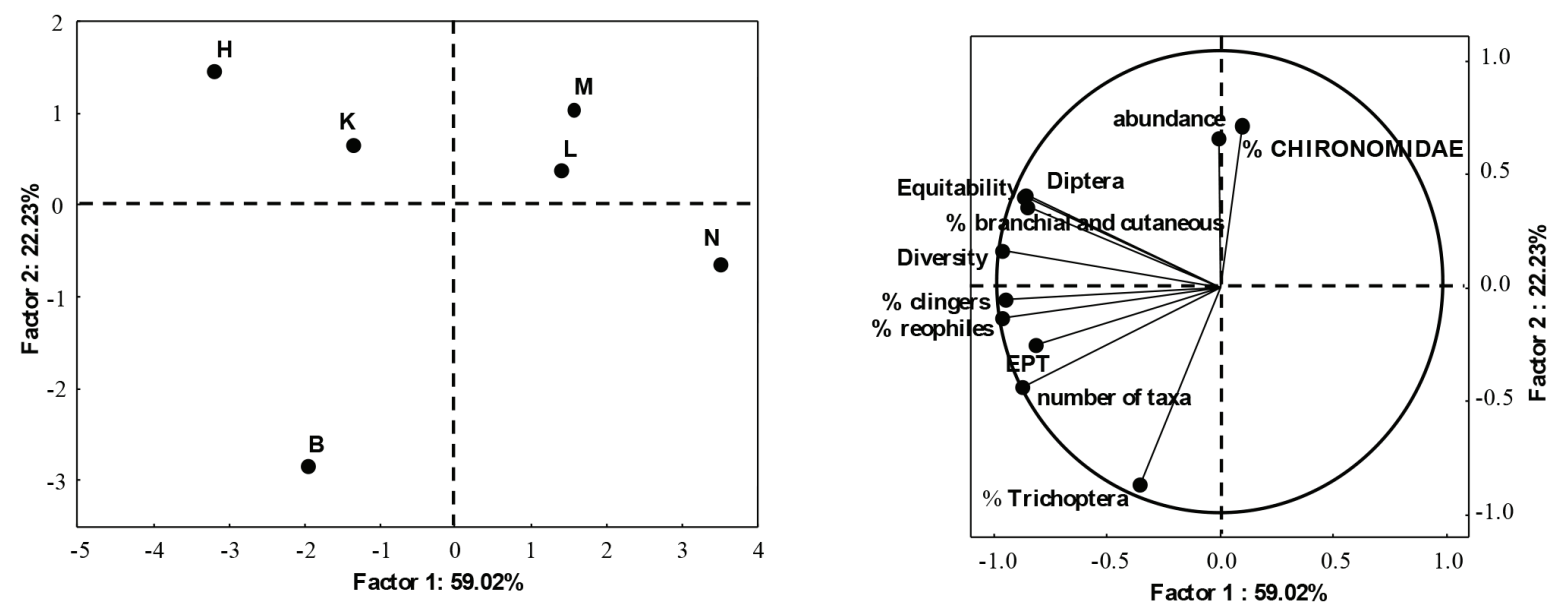

Figure 7. Principal components analysis (PCA) based on the mean values of the macroinvetebrate metrics: left) sample ordination of all sampling sites in the space formed by the two first factors; right) correlation circle of metrics with the two first factors. Análise em componentes principais (PCA) baseada nos valores médios das métricas calculadas com base nos dados de macroinvertebrados: esquerda) ordenação dos pontos de amostragem no espaço formado pelos dois primeiros fatores; direita) círculo de correlação das métricas com os dois primeiros fatores.

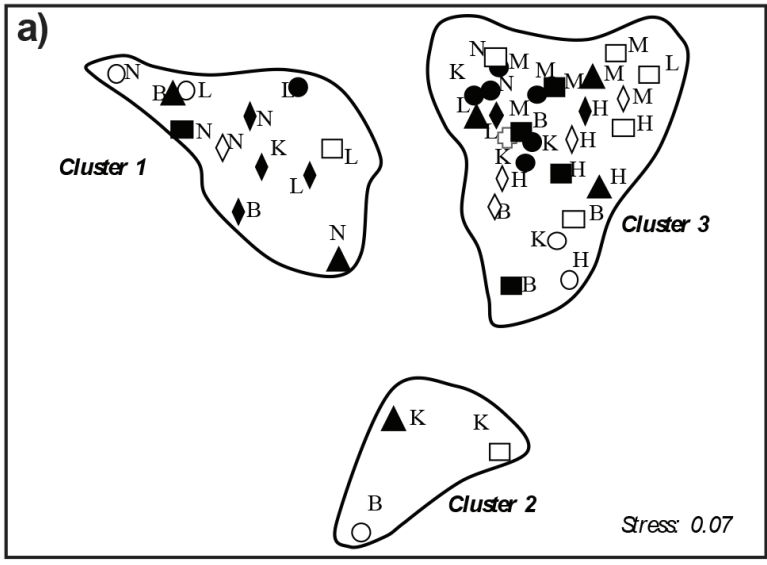

- dec'15O dec'16 mar'16 $\diamond$ mar'17 $\square$ jun'16 $\square$ jun'17 $\Delta$

sep' 16

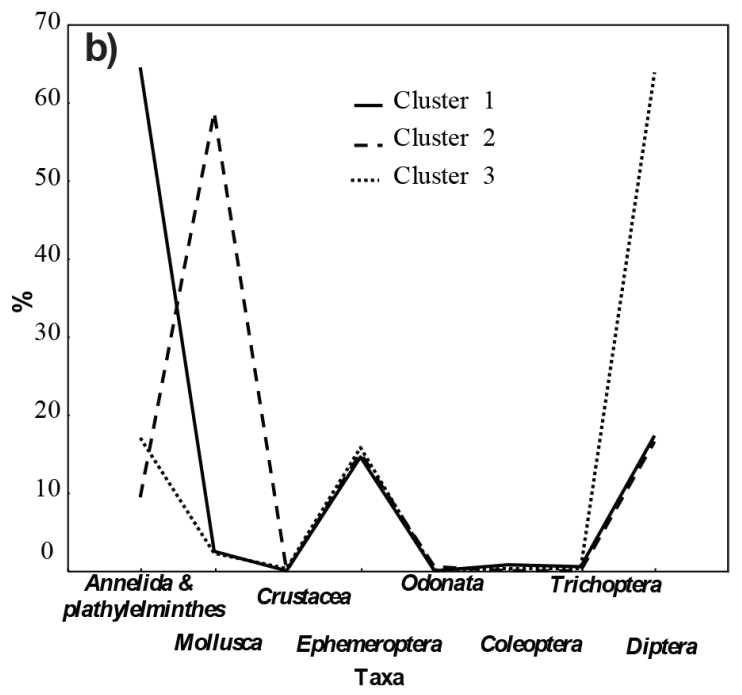

Figure 8. Sample ordination made by the n-MDS technique with Euclidean distances between samples using taxa (a) and average of each taxa in each cluster (b). Ordenação das amostras através da análise n-MDS usando as distâncias euclideanas entre os taxa(a) e média de cada taxa em cada cluster (b).

ANOSIM test: $\mathrm{R}_{\text {global }}=0.960$ 
(Fig. S2 and Fig. 8) and there is a higher percentage of Ephemeroptera (Fig. S2 and Fig. 8) showing the highest variability of respiratory types (Fig. S2 and Fig. 9), lower percentage of shredder organisms (Fig. S2 and 10), greater diversity of organisms considering habitat preference (Fig. S2 and

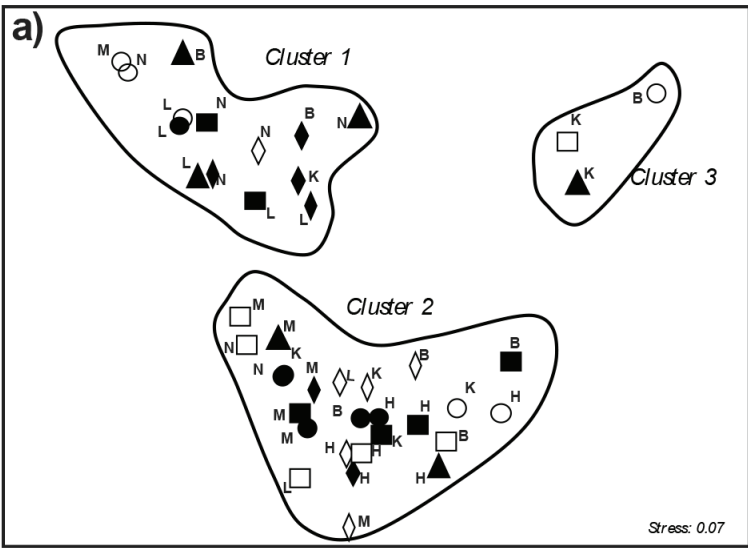

Odec'15 O dec'16 mar'16 \mar'17 पjun'16 $\square$ jun'17 $\Delta$ sep'16

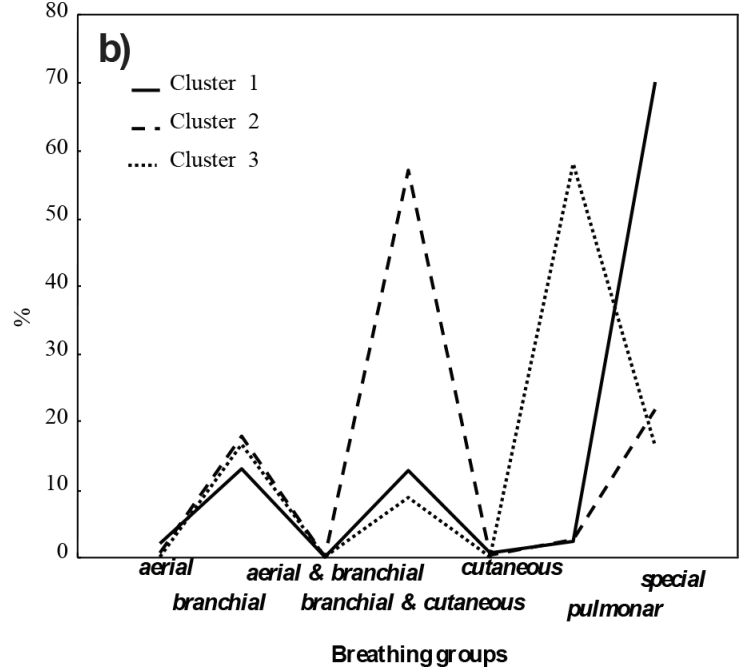

Figure 9. Sample ordination made by the n-MDS technique with Euclidean distances between samples using the functional respiratory groups (a) and average of each functional respiratory group in each cluster (b). Ordenação das amostras através da análise $n$-MDS usando as distâncias euclideanas entre os grupos funcionais respiratórios(a) e média de cada grupo funcional respiratório em cada cluster (b).

ANOSIM test: $\mathrm{R}_{\text {global }}=0.959$

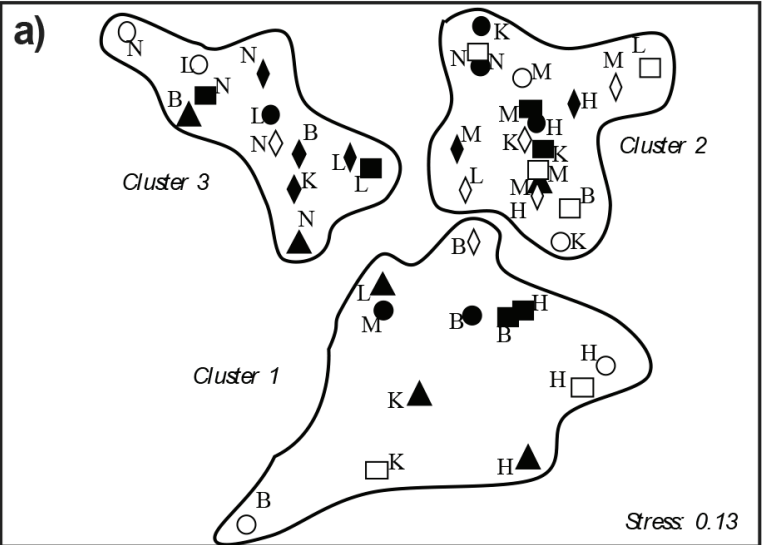

dec'150 dec'16 mar'16 $\diamond$ mar'17 $\square$ jun'16 $\square$ jun'17 $\Delta$ sep'16

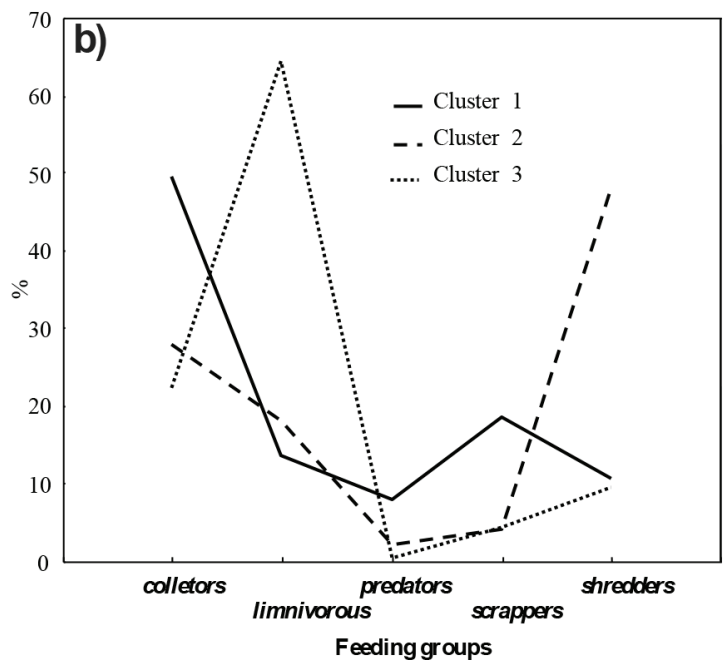

Figure 10. Sample ordination made by the n-MDS technique with Euclidean distances between samples using the functional feeding groups (a) and average of each functional feeding group in each cluster (b). Ordenação das amostras através da análise n-MDS usando as distâncias euclideanas entre os grupos funcionais alimentares(a) e média de cada grupo funcional alimentar em cada cluster (b).

ANOSIM test: $\mathrm{R}_{\text {global }}=0.800$ 
11) and higher percentage of limnophilic organisms (Fig. S2 and Fig. 12), with special respiratory strategies (Fig. S2 and 9), limnivorous and shredders (Fig. S2). The sampling sites L, M and $\mathrm{N}$ present communities formed almost exclusively by Diptera of the Chironomidae family and by Oligochaeta that live buried in the substrate (Figs. S2 and 11) and at sites with lower current velocity (Figs. S2 and 12).

\section{DISCUSSION}

\section{WWTP's influence of the water quality and on the benthic macroinvertebrate communities' structure of the river Tinto}

The Tinto river is a small river with a high degree of degradation of its banks and riverbed along most of its course, as expected in most urban rivers, due to the high urban pressure. Tunneling of parts of the river, river embankment, dwellings occupation explain the little vegetation present along the banks (almost all QBR values under 50) and little capacity of fixation of aquatic vegetation (Roesner, 1997; Li et al., 2009; Birk et al.,
2012). Its water quality ranging from medium to bad due to the high organic and nutrient load from some diffuse or punctual discharges of untreated domestic effluent and WWTP discharges, is reflected in the high concentrations nitrates, nitrites, ammonia and phosphates in almost all sampling sites except the one closest to the source (site B) (INAG, 2009). This pollution is confirmed by high $\mathrm{BOD}_{5}$ values, an indicator of organic contamination since it assesses the amount of oxygen present in the water that is spent for the mineralization of the various nutrients through biological processes (Dyer et al., 2003; Dodds, 2006; Gucker et al., 2006; Ladrera \& Prat, 2013).

This confirms the impact of the densely urbanized area surrounding the river except for the last $4 \mathrm{~km}$ section where there is an urban leisure park and some agricultural areas that contribute to a more natural bank appearance ( $\mathrm{Li}$ et al., 2009). Our results also show that there is an increasing degradation of water quality, which is conditioned by the occasional discharges of untreated effluents from the urbanized areas, but which in the last kilometers is further degraded

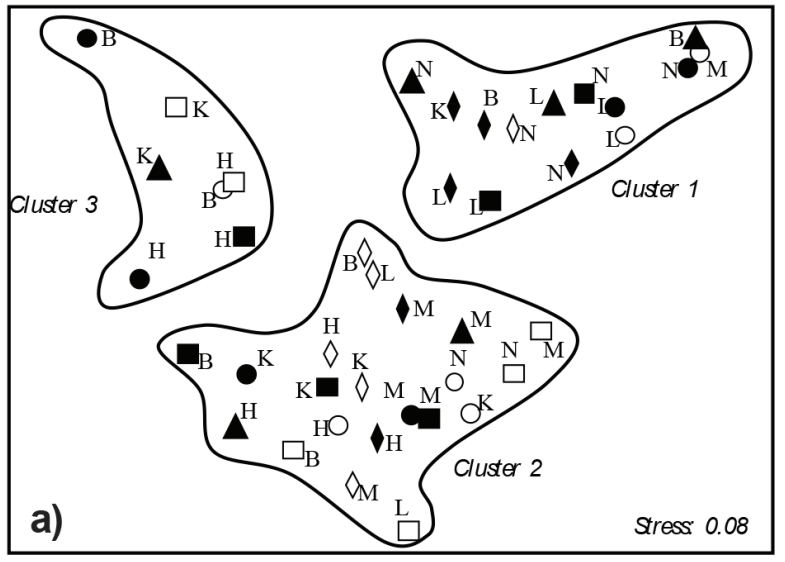

- dec'150 dec'16 mar'16 $\$ mar'17 $\square$ jun'16 $\square$ jun'17 $\Delta$ æep'16

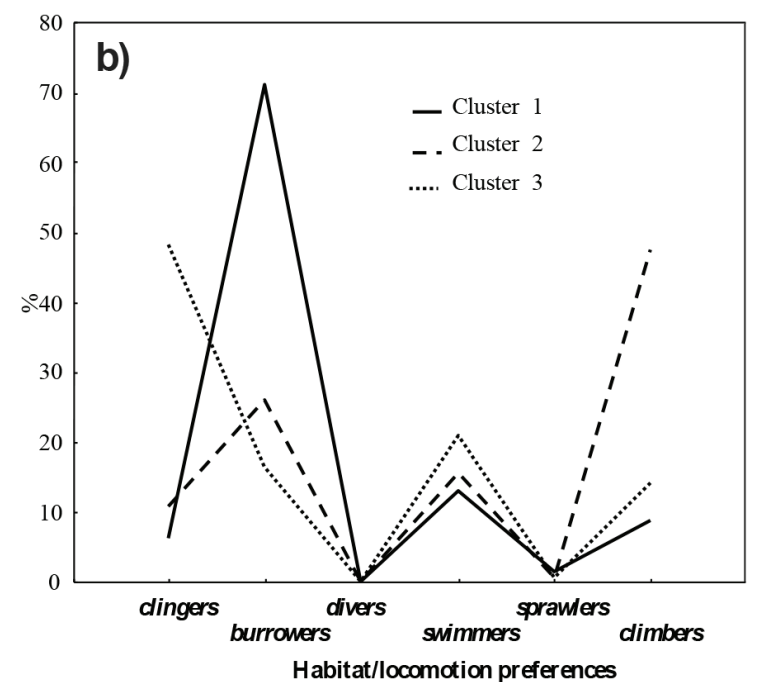

Figure 11. Sample ordination made by the n-MDS technique with Euclidean distances between samples using the habitat/locomotion groups (a) and average of each habitat/locomotion group in each cluster (b). Ordenação das amostras através da análise n-MDS usando as distâncias euclideanas entre os grupos de preferência por habitat/locomoção (a) e média de cada grupo de preferência por habitat/locomoção em cada cluster (b).

ANOSIM test: $\mathrm{R}_{\text {global }}=0.879$ 
due to the high WWTPs' effluent flow located upstream of sites $\mathrm{L}$ and $\mathrm{N}$. These facts can explain the difficulty in determining thereal impact of the WWTP discharges on urban rivers because there are multiple effects acting together (Rueda et al., 2002, Bruns, 2005; Culp \& Baird, 2006).

It should be noted that although the WWTP's operating in accordance with the Portuguese law and meeting the requirements in term of final quality of the treated water (still worse than water quality of a natural river) and as their flow discharge in the river is equivalent to the river flow, the result clear compromises its water quality by increasing the organic load.

The composition and structure of the benthic macroinvertebrate community of the Tinto River reflects the conditions of the ecosystem in terms of colonization and survival of aquatic species as indicated by other studies in urban rivers (Meyer et al., 2005, Mahazar et al., 2013). This may have relevant consequences as invertebrates play an important role in maintaining the structural and functional integrity of aquatic ecosystems (Wallace \& Webster, 1996; Covich et al., 2004).

The Tinto River is an ecosystem that has mod- erately stable and diversified habitats availability, since the materials that constitute the river bed have a diversified granulometry with a predominance of the coarser materials, except at site $\mathrm{N}$, the closest site to the mouth of the river and where begins the accumulation of the finest sediments transported along the whole river. This fact makes that the availability of habitats does not become a limiting factor to the fixation of organisms with different habits of life as shown by the AVH value. Therefore, the physical and chemical quality of water seems to be the predominant factor for the survival of organisms in Rio Tinto. The composition and functional structure of communities is dependent on the greater or lesser sensitivity of organisms to factors such as the availability of dissolved oxygen and the concentration of organic matter in water (Paul \& Meyer, 2001; Meyer et al., 2003; Allen, 2004; Walsh et al., 2005, Deacon et al., 2005; Cuffney et al., 2010)

In fact, downstream the WWTP, although hydro-morphological factors seem to favor a greater diversity of habitats and thus organisms, the degradation of water quality causes some notable changes in the structure and composition

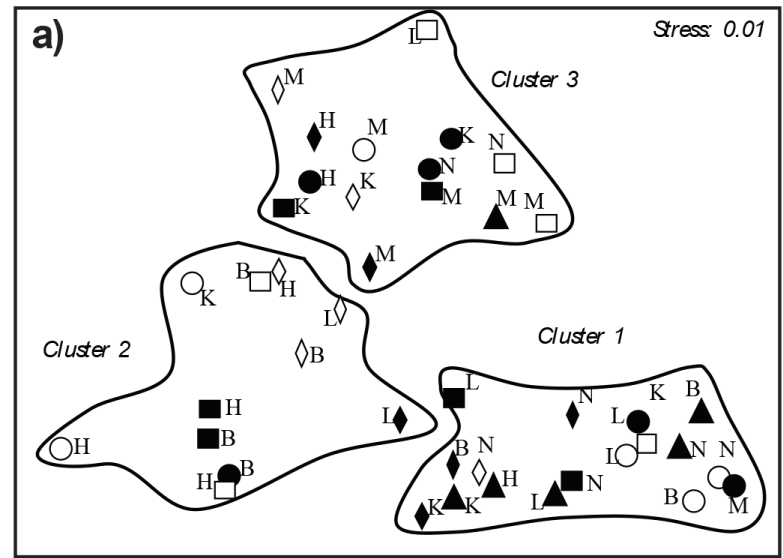

dec'15○ dec'16 mar'16 $\diamond$ mar'17 $\square$ jun'16 $\square$ jun'17 $\triangle$ sep'16

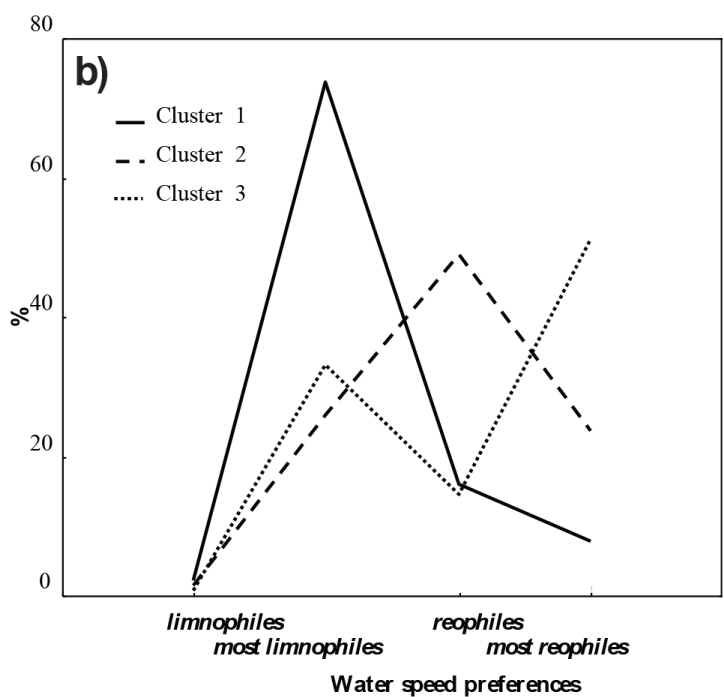

Figure 12. Sample ordination made by the n-MDS technique with Euclidean distances between samples using the water speed preference groups (a) and average of each water speed preference group in each cluster (b). Ordenação das amostras através da análise n-MDS usando as distâncias euclideanas entre os grupos de preferência por velocidade de corrente (a) e média de cada grupo de preferência por velocidade de corrente em cada cluster (b).

ANOSIM test: $\mathrm{R}_{\text {global }}=0.857$ 
of these communities (Dyer \& Wang, 2002; Suozzo, 2005; Poulton et al., 2015) noticed by:

- Great abundance of organisms;

- Low taxonomic diversity with predominance of Chironomidae e Annelida (Spellman \& Drinan, 2001; Ozkan et al., 2010; Silva et al., 2008);

- Reduction in the number of organisms that are dependent on oxygen dissolved in the water for survival, such as those with branchiall and / or cutaneous respiration (Jesus, 2008).

\section{Benthic macroinvertebrate communities' structure and environmental conditions}

There is not a clear relation between some of the results obtained with the environmental parameters and the composition and structure of the benthic macroinvertebrates communities. Based on the three groups defined by the hydro-morphological parameters, physical and chemical parameters and data from the benthic macroinvertebrate communities (group 1: site B; group 2: sites $\mathrm{H}$ and $\mathrm{K}$; group 3: sites $\mathrm{L}, \mathrm{M}$ and $\mathrm{N}$ ), there seems to be a certain contradiction between the results from the physical and chemical parameters and from the hydro-morphological parameters analysis. The physical and chemical water quality decreases towards downstream (from site B to site $\mathrm{N}$ ), while, the hydro-morphological quality improves along the course of the river (from site B to site $\mathrm{N}$ ). even though hydro-morphological factors seem to favor a greater diversity of organisms, as demonstrated by the values of AVH and QBR (Compin \& Céréghino, 2007; Li et al., 2009; Allen \& Vaughn, 2010; McGoff et al., 2013),

This discrepancy is apparent and is due to the fact that the whole river is in a densely urbanized area, with the banks occupied by a very dense urban network, except in the last kilometers (sites $\mathrm{L}, \mathrm{M}$ and $\mathrm{N}$ ) where there is an urban leisure park and some agricultural areas and land occupied by the WWTP's, that give the banks. These results are in agreement with studies that show the great difficulty in determining the impact of WWTP discharges on urban rivers due to the combined effect of several environmental stressors (Culp \& Baird, 2006).

Benthic macroinvertebrates community shows great heterogeneity, but tend to group like the physical-chemical parameters quality levels. This result suggests that the characteristics of the organisms found in the groups agree with the physical-chemical parameters quality levels, despite the habitat conditions show otherwise, especially when analyzing the community considering characteristics such as the preference of organisms by habitat type and mode of locomotion, current velocity preferences and type of food.

When analyzing the community metrics and index of biological quality of the water, we can establish some relations:

- Lower values of oxygen saturation decrease the abundance of organisms with branchial and/or cutaneous respiration;

- Higher levels of organic pollution result in less EPT and greater abundance of Diptera and Annelida;

- Annelida are more abundant in areas dominated by fine sediments since they have limnivore type feeding and live buried in the substrate;

- Individuals of the family Baetidae that have branchial respiration are present even in places where the water quality is not good because they have great capacity of locomotion in the water column which allows them to take refuge quickly and to recolonize other places.

\section{Identification of metrics and / or parameters that better describe the effects caused by the discharge of the WWTP's on the quality of the Tinto river}

The identification of metrics that allow the assessment of the impacts of WWTPs in urban rivers is a task that has been attempted in several studies (Yoder \& Rankin, 1995; Burns, 2005), to speed up the process of evaluation and monitoring of this type of aquatic systems.

Thus, after the combined analysis of all parameters, metrics and calculated indexes, there are some parameters that somehow seem to have translated in a more reliable way the true impact of the WWTPs in the Tinto river:

- Conductivity: the variation of its values translates he variations of the quality of the water in the different sampling sites;

- Relation between oxygen saturation and $\mathrm{BOD}_{5}$ : the study of these two parameters togeth- 
er, allow to separate the sampling sites into three groups that correspond to the field observations;

- Relation between \% EPT and \% Chironomidae plus Oligochaeta: these are metrics show the variation of community along the several sampling sites, even being a very impoverished community;

- The \% of organisms with branchial and cutaneous respiration seems to be the functional characteristic of the community that best separates the sampling sites. This should be related to the fact that the concentration of oxygen in the water is a parameter that better translates its level of pollution, being a determining factor for the survival of organisms that are completely dependent on the aquatic environment to obtain the necessary oxygen (Jesus, 2008).

\section{CONCLUSIONS}

There are sections of the Tinto river in which the natural hydro-morphological characteristics have been greatly altered by embankments, channeling, and riverbank settlements. The ecological status of the Tinto River varies between insufficient and bad based on water quality and environmental parameters and benthic macroinvertebrates communities.

Macroinvertebrate communities are, generally, taxonomically poor and have relatively low values of diversity. Annelida and Diptera are the dominant organisms over other faunal groups present such as Ephemeroptera and Mollusca.

The water quality and the benthic invertebrates community are significantly and negatively affected by the WWTPs, in spite of the improvement of the hydro-morphological conditions downstream of the WWTPs.

The metrics that better evaluate the impact of the WWTPs are related to the taxonomic composition of the samples and those related to the respiratory physiology of the organisms.

\section{ACKNOWLEDGEMENTS}

Research work funded by national funds provided by FCT - Fundação para a Ciência e a Tecnologia, in the scope of FCT Project UID/Multi/04546/ 2013.

\section{REFERENCES}

ALBA-TERCEDOR, J., P. JÁIMEZ-CUÉLLAR, M. ÁlVAREZ, J. AVILÉS, N. BONADA, J. CASAS, A. MELLADO, M. ORTEGA, I. PARDO, N. PRAT, M. RIERADEVALL, S. ROBLES, C. SÁINZ-CANTERO, A. SÁNCHEZ ORTEGA, M. SUÁREZ, M. TORO, M. VIDAL-ABARCA, S. VIVAS \& C. ZAMORA-MUÑOZ. 2002. Caracterización del estado ecológico de ríos mediterráneos ibéricos mediante el índice IBMWP (antes BMWP'). Limnetica, 21 (3-4): 175-185.

ALLEN, J. D. 2004. Landscapes and riverscapes: The influence of land use on stream ecosystems. Annual Review of Ecology, Evolution and Systematics, 35:275-284.

ALLEN D. C. \& C. C. VAUGHN. 2010. Complex hydraulic and substrate variables limit freshwater mussel species richness and abundance. Journal of the North American Benthological Society, 29:383-394.

APHA, 1999. Standard Méthods for the Examination of Water and Wastewater. $18^{\circ} \mathrm{ed}$.

BARBOUR M. T., 1997. The re-invention of biological assessment in the U. S. Human and Ecological Risk Assessment, 3(6): 933-940.

BIRK, S., W. BONNE, A. BORJA, S. BRUCET, A. COURRAT, S. POIKANE, A. SOLIMINI, W. VAN DE BUND, N. ZAMPOUKAS \& D. HERING. 2012. Three hundred ways to assess Europe's surface waters: An almost complete overview of biological methods to implement the Water Framework Directive. Ecological Indicators, 18: 31-41.

BRUNS, D. A. 2005. Macroinvertebrate Response to Land Cover, Habitat, and Water Chemistry in a Mining-Impacted River Ecosystem: A GIS Watershed Analysis. Aquatic Sciences, 67: 403-423.

CASATTI, L., F. LANGEANI, A. M. SILVA \& R. M. C. CASTRO. 2006. Stream fish, water and habitat quality in a pasture dominated basin, Southeastern Brazil. Brazilian Journal of Biology, 66(2B): 681-696.

CASTILlO, L. E., E. MARTÍNEZ, C. RUEPERT, C. SAVAGE. M. GILEK, M. PINNOCK \& E. SOLIS. 2006. Water quality and macroinvertebrate community response 
following pesticide applications in banana plantation, Limon, Costa Rica. The Science of the Total Environment, 367 (1): 418-32.

CLARCKE K. R. \& R. M. WARWICK. 1994. Change in marine communities: an approach to statistical analysis and interpretation. Plymouth Marine Laboratory, UK.

CLIMATEDATA, 2017. https://en.climate-data. org. Consulted at 23rd march 2017.

COHEN, J. E. 2003. Human Population: The Next Half Century. Science, 302: 1172-1175.

COMPIN, A. \& R. CÉRÉGHINO. 2007. Spatial patterns of macroinvertebrates functional feeding groups in streams in relation to physical variables and land-cover in south-western France. Landscape Ecology, 22: 1215-1225.

CONCEPCIÓN, E. D., M. MORETTI, F. ALTERMATT, M. P. NOBIS \& M. K. OBRIST. 2015. Impacts of urbanisation on biodiversity: the role of species mobility, degree of specialisation and spatial scale. Oikos, 124: 1571-1582

COVICH, A. P., M. AUSTEN, F. BAERLOCHER, E. CHAUVET, B. J. CARDINALE, C. L. BILES, P. INCHAUSTI, O. DANGLES, $M$. SOLAN, M. O. GESSENR, B. STATZNER $\&$ B. MOSS. 2004. The role of biodiversity in the functioning of freshwater and marine benthic ecosystems. Bioscience, 54: 767-775.

CUFFNEY, T. F., R. A. BRINGHTBILL, J. T. MAY \& I. R. WAITE. 2010. Responses of benthic macroinvertebrates to environmental changes associated with urbanization in nine metropolitan areas. Ecological Applications, 20: 1384-1401.

CULP, J. M. \& D. J. BAIRD. 2006. Establishing Cause-Effect Relationships in Multi-Stressor Environments. In: Hauer, F.R. and Lamberti, G.A., Eds., Methods in Stream Ecology, 2nd Edition, Elsevier, Oxford, 835-854.

DEACON, J. R., S. A. SOULE \& T. E. SMITH. 2005. Effects of urbanization on stream quality at selected sites in the seacoast region of New Hampshire, 2001-03. US Geological Surey Investigations Report, 2005-5103.

Dec. Law no 58/2005.

Dec. Law no ${ }^{\circ} 77 / 2006$.

Dec. Law $n^{\circ} 103 / 2010$.

Dec. Law n ${ }^{\circ} 245 / 2009$.
Diretive 2000/60/CE do parlamento Europeu e do Conselho, 23 de outubro de 2000.

DODDS, W. K. 2006. Eutrophication and Trophic State in Rivers and Streams. Limnology and Oceanography, 51: 671- 680.

DYER, S. D. \& X. WANG. 2002. A Comparison of Stream Biological Responses to Discharge from Wastewater Treatment Plants in High and Low Population Density Areas. Environmental Toxicology and Chemistry, 21: 1065-1075.

DYER, S. D, C. PENG, D. C. MCAVOY, N. J. FENDINGER, P. MASSCHELEYN, L. V. CASTILLO \& J. M. U. LIM. 2003. The influence of untreated wastewater to aquatic communities in the Balatuin River, The Philippines. Chemosphere, 52 (1): 43-53.

EPA, 1999. Rapid bioassessment protocols dos use in streams and wadeable rivers: periphyton, benthic macroinvertebrates and fish. 2nd ed., United states.

FINKENBINE, J. K., J. W. ATWATER, \& D. S. MAVINIC. 2000. Stream Health after Urbanization. Journal of the American Water Resources Association, 36: 1149-1160.

FOLT, C. L., C. Y. CHEN, M.V. MOORE \& J. BURNAFORD. 1999, Synergism and Antagonism among Multiple Stressors. Limnology and Oceanography, 44: 864-877.

FUKUSHIMA, S. \& S. KANADA. 1999. Effects of Chlorine on Periphytic Algae and Macroinvertebrates in a Stream Receiving Treated Sewage as Maintenance Water. Japanese Journal of Limnology, 60: 569-583.

GERHARDT, A., L. JANSSENS DE BISTHOVEN \& A. SOARES. 2004. Macroinvertebrate response to acid mine drainage: community metrics and online behavioural toxicity bioassay. Environmental Pollution, 130 (2): 263-274.

GILLER, P. S., B. MALMQVIST. 1998. The biology of streams and rivers. Oxford University Press

GRANTHAM, T. E., M. CAÑEDO-ARGÜELLES, I. PERRÉE, M. RIERADEVALL $\&$ N. PRAT. 2012. A mesocosm approach for detecting stream invertebrate community responses to treated wastewater effluent. Environmental Pollution, 160: 95-102. 
GRIMM, N. B., J. M. GROVE, S. T. A PICKETT \& C. L. REDMAN. 2000. Integrated Approaches to Long-Term Studies of Urban Ecological Systems. Bioscience, 50: 571-584. GÜCKER, B., M. BRAUNS \& M. T. PUSCH. 2006. Effects of wastewater treatment plant discharge on ecosystem structure and function of lowland streams. Journal of the North American Benthological Society, 25 (2): 313-329.

GULIS, V. \& K. SUBERKROPP. 2003. Leaf litter decomposition and microbial activity in nutrient enriched and unaltered reaches of a headwater stream. Freshwater Biology, 48: 123-134.

HASEENA M., M. F. MALIK, A. JAVED, S. ARSHAD, N. ASIF, S. ZULFIQAR \& J. HANIF. 2017. Water pollution and human health. Environ Risk Assess Remediat., 2017;1(3):16-19.

HEISKANEN, A. S., W. VAN DE BUND, A. C. CARDOSO \& P. NOGES. 2004. Towards good ecological status of surface waters in Europe Interpretation and harmonisation of the concept. Water Science \& Technology, 49 (7): 169-177.

HRODEY, P. J., B. J. KALB \& T. M. SUTTON. 2008. Macroinvertebrate community response to large-woody debris additions in small warmwater streams. Hydrobiologia, 605 (1): 193-207.

INAG, I. P. 2008a. Manual para a avaliação biológica da qualidade biológica da qualidade da água em sistemas fluviais segundo a Directiva Quadro da Água. Protocolo de amostragem e análise para os macroinvertebrados bentónicos. MAOTDR.

INAG, I. P. 2008b.Tipologia de rios em Portugal Continental no âmbito da implementação da Directiva Quadro da Água. I - Caracterização abiótica. MAOTDR.

INAG, I. P. 2009. Critérios para a classificação do estado das massas de água superficiais. Rios e albufeiras. MAOTDR

JESUS, T. 2001. Centrais hidroelétricas de pequena dimensão: impacto na dinâmica da comunidade de macroinvertebrados bentónicos e na variação da qualidade da água (Mini-hídrica de Vila Viçosa e "Cascata" do
Alva). Dissertação de doutoramento apresentada á Faculdade de Ciências da Universidade do Porto, $235 \mathrm{pp}$.

JESUS, T. 2008. Ecological, anatomical and physiological traits of benthic macroinvertebrates: Their use on the health characterization of freshwater ecosystems. Limnetica, 27 (1): 79-92.

KOSMALA, A., S. CHARVET, M. C. ROGER, \& B. FAESSEL. 1999. Impact Assessment of a Wastewater Treatment Plant Effluent Using Instream Invertebrates and the Ceriodaphnia dubia Chronic Toxicity Test. Water Research, 33: 266-278.

LADRERA R. \& N. PRAT. 2013. Changes in macroinvertebrate community abd biotic indices associated with streamflow regulation and wastewater inputs in Sierra Cebollera Natural Park (La Rioja, Northern Spain). Limnetica, 32(2): 353-372.

LEMOS R. V. 2010. Reabilitação de Ribeiras Urbanas: aplicação ao caso do rio Tinto no concelho do Porto. Dissertação de mestrado apresentada à Faculdade de Engenharia do Porto, FEUP.

LI T., F. SHILling, J. THORNE, J. LI, H. SCHOTT, R. BOYNTON \& A. M. BERRY. 2010. Fragmentation of China's landscape by roads and urban areas. Landscape Ecology, 25: 839-853.

MAHAZAR, A., M. SHUHAIMI-OTHMAN, A. A. KUTTY \& M. N. M. DESA. 2013. Monitoring urban river water quality using macroinvertebrate and physico-chemical parameters: case study of Penchala river, Malaysia. Pakistan Journal of Biological Sciences, 2013: 1-9.

MEILLĖRE A., F. BRISCHOUX, C. PARENTEAU \& F. ANGELIER. 2015. Influence of Urbanization on Body Size, Condition, and Physiology in an Urban Exploiter: A MultiComponent Approach PLoS One. 2015; 10(8)

MEYER, J. L., M. J. PAUL, \& K. TAULBEE. 2005. Stream Ecosystem Function in Urbanizing Landscapes. Journal of the North American Benthological Society, 24: 602-612.

JESUS, T., A. MONTEIRO, A. AMADO, I. ABREU, M. J: GUERREIRO \& M. COSTA. 2017. Avaliação de alguns parâmetros 
relativos ao estado ecológico do rio tinto e de alguns dos seus afluentes: monitorização (out'15-set'17) relatório final. Relatório Fina do Projeto apresentado publicamente à LIPOR.

MUNNÉ A., C. SOLÁ \& N. PRAT. 1998. QBR: Un índice rápido para la evaluación de la calidad de los ecossistemas de ribera. Tecnologia del Agua: artículos técnicos, 175: 20-37.

MUNNÉ, A. \& N. PRAT. 2009. Use of macroinvertebrate-based multimetric indices for water quality evaluation in Spanish Mediterranean rivers: an intercalibration approach with the IBMWP index. Hydrobiologia, 628 (1): 203-225.

NORTHINGTON, R. M. \& A. E. HERSHEY. 2005. Effects of Stream Restoration and Wastewater Treatment Plant Effluent on Fish Communities in Urban Streams. Freshwater Biology, 51: 1959-1973.

O'DRISCOLL M., S. CLINTON, A. JEFFERSON, A. MANDA \& S. MCMILLAN. 2010. Urbanization Effects on Watershed Hydrology and In-Stream Processes in the Southern United States. Water, 2: 605-648

ORTIZ, J. D. \& M. A. PUIG. 2007. Point source effects on density, biomass and diversity of benthic macroinvertebrates in a Mediterranean stream. River Research and Applications, 23 (2): 155-170.

OZKAN, N., J. MOUBAYED-BREIL \& B. CAMUR-ELIPEK. 2010. Ecological analysis of chironomid larvae (dipteral, Chironomidae) in Ergene River basin (Turkish Thrace). Turkish Journal of Fisheries and Aquatic Sciences, 10: 93-99.

PARRINELLO, G. 2014. Urban Rivers: Remaking Rivers, Cities, and Space in Europe and North America, The AAG Review of Books, 2:3: 94-96.

PASCOAL, C., F. CASSIO, A. MARCOTEGUI, B. SANZ, \& P. GOMES. 2005. Role of Fungi, Bacteria, and Invertebrates in Leaf Litter Breakdown in a Polluted River. Journal of the North American Benthological Society, 24: 784-797.

PAUL, M. J. \& J. L. MEYER. 2001. Streams in the Urban Landscape. Annual Review of Ecology and Systematics, 32: 333-365.

PINHO, P., S. SANTOS, R. DIAS, M. FERREI-
RA, C. SILVA, M. TORRES, F. MOURA E SÁ \& R. FERNANDES. 2009. Atlas da Grande Área metropolitana do Porto. FEUP. Junta Metropolitana do Porto.

PLATTS W. S., W. F. MEGAHAN \& G. W. MINSHALL. 1983. Methods for evaluating stream, riparian and biotic conditions. USDA.

POULTON, B. C., J. L. GRAHAM, T. J. RASMUSSEN \& M. L. STONE. 2015. Responses of Macroinvertebrate Community Metrics to a Wastewater Discharge in the Upper Blue River of Kansas and Missouri, USA. Journal of Water Resource and Protection, 7: 1195-1220.

QUINN, J. M. \& C. W. HICKEY. 1990. The Magnitude of the Effects of Substrate Particle Size, Recent Flooding, and Catchment Development on Benthic Invertebrates in $88 \mathrm{New}$ Zealand Rivers. New Zealand. Journal of Marine and Freshwater Research, 24: 411-427.

RIERADEVALL, M., N. BONADA \& N. PRAT. 1999. Community structure and water quality in the Mediterranean streams of a natural park (St. Llorenç del Munt, NE Spain). Limnetica, 17: 45-56.

ROESNER, L. A., Ed. 1997. Effects of watershed development and management on aquatic Ecosystems. In: Proceedings of an Engineering Foundation Conference, America Society of Civil Engineers, New York, 384.

RUEDA, J., A. CAMACHO, F. MEZQUITA, R. HERNÁNDEZ \& J. R. ROCA. 2002. Effect of episodic and regular sewage discharges on the water chemistry and macroinvertebrate fauna of a Mediterranean stream. Water, Air, \& Soil Pollution, 140 (1): 425-444.

SHEEHAN, M. O. 2001. City Limits: Putting the Brakes on Sprawl. Worldwatch Paper, No. 156, Worldwatch Institute, Washington DC.

SILVA, F. L., S. S. RUIZ, G. L. BOCHINI \& D. C. MOREIRA. 2008. Functional feeding habits of Chironomidae larvae (Insecta, Diptera) in a lotic system from Midweastern region of Sao Paulo state, Brazil. Pan-American Journal of Aquatic Sciences, 3: 135-141. SPÄNHOFF, B., R. BISCHOF, A. BÖHME, S. LORENZ, K. NEUMEISTER, A. NÖTH- 
LICH \& K. KÜSEL. 2007. Assessing the impact of effluents from a modern wastewater treatment plant on breakdown of coarse particulate organic matter and benthic macroinvertebrates in a lowland river. Water, Air, \& Soil Pollution, 180 (1): 119-129.

SPELLMAN, F. R. \& J. DRINAN. 2001. Stream Ecology and self purification: An introduction. 2nd. Edn., Tchnomic Publishing Company, Pennsylvania.

SUCKLING, D. M. 1982. Organic Wastewater Effects on Benthic Invertebrates in the Manawatu River. New Zealand Journal of Marine and Freshwater Research, 16: 263-270.

SUOZZO, K. 2005. The Use of Aquatic Insects and Benthic Macroinvertebrate Communities to Assess Water Quality Upstream and Downstream of the Village of Stamford Wastewater Treatment Facility. In: Proceedings of the 38th Annual Report of the SUNY Oneonta Biological Field Station, Biological Field Station, Cooperstown, 141-151.

TACHET, H., P. RICHOUX, M. BOURNARD, P. USSEGLIO-POLATERA. 2000. Invertebrés d'eau douce. Systématique, biologie, écologie. CNRS editions.

VIEIRA, N. M. 2009. Qualidade Química e bacteriológica das Águas das ribeiras do Porto. Dissertação de mestrado apresentada à Universidade de Aveiro, Universidade de Aveiro.

VIVAS, S., J. CASAS, I. PARDO, S. ROBLES, N. BONADA, A. MELLADO, N. PRAT, J. ALBATERCEDOR, M. ÁlVAREZ \& M. M.
BAYO. 2002. Aproximación multivariante en la exploración de la tolerancia ambiental de las familias de macroinvertebrados de los ríos mediterráneos del proyecto GUADALMED. Limnetica, 21: 149-173.

WALLACE, J. B. \& J. R. WEBSTER. 1996. The role of macroinvertebrates in stream function. Annual Review of Entomology, 41: 115-139.

WALSH, C. R., A. H. ROY, J. W. FEMINELLA, P. D. COTTINGHAM, P. M. GROFFMAN, \& R. P. MORGAN II. 2005. The Urban Stream Syndrome: Current Knowledge and a Search for a Cure. Journal of the North American Benthological Society, 24: 706-723.

YODER, C. O. \& E. T. RANKIN. 1995. Biological Response Signatures and the Area of Degradation Value: New Tools for Interpreting Multimetric Data. In: Davis, W.S. and Simon, T.P., Eds., Biological Assessment and Criteria-Tools for Water Resource Planning and Decision Making, Lewis Publ., Boca Raton, 263-286.

YOUNG, R. G., C. D. MATTHAEI, \& C. R. TOWNSEND. 2008. Organic Matter Breakdown and Ecosystem Metabolism: Functional Indicators for Assessing River Ecosystem Health. Journal of the North American Benthological Society, 27: 605-625.

ZHANG, Y., L. LIU, L. CHENG, Y. CAI, H. YIN, J. GAO \& Y. GAO. 2014. Macroinvertebrate assemblages in streams and rivers of a highly developed region (Lake Taihu Basin, China). Aquatic Biology, 23: 15-28

Con el patrocinio de:

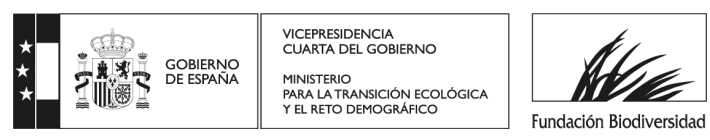

